\title{
Covid-19 and In(di)genuity: Lessons from Indigenous resilience, adaptation, and innovation in times of crisis
}

\author{
Kiera Brant-Birioukov ${ }^{1}$ (D)
}

Accepted: 25 February 2021 / Published online: 28 April 2021

(C) UNESCO IBE 2021

\begin{abstract}
In the midst of the global Covid-19 pandemic, educators are invited to pause and reconsider the legacies this crisis will leave for future generations. What lessons do we take forward in a post-Covid-19 curriculum? This article contemplates the value of Indigenous resilience, innovation, and adaptation in times of crisis- "In(di)genuity", if you will-and considers its implications on Indigenous knowledge and the curricular discourse more broadly. Despite encouraging developments in Indigenous education since the Truth and Reconciliation Commission, a settler historical consciousness continues to pervade the modern discourse of Indigenous education, insofar as Indigenous knowledge is often perceived as outdated, irrelevant, or inferior to Western knowledge systems. This problematic misconception ignores the resilience, innovation, and adaptation that Indigenous peoples have demonstrated in the face of historical crises. This article offers an Indigenous perspective on crisis, grief, and renewal in the context of Covid-19 and advocates for the renewal of the Canadian curricular landscape.
\end{abstract}

Keywords Indigenous education · Covid-19 $\cdot$ Curriculum $\cdot$ Resilience $\cdot$ Innovation · Renewal

“The world isn't ending", she went on. "Our world isn't ending. It already ended. It ended when the Zhaagnaash came into our original home down south on that bay and took it from us. That was our world. When the Zhaagnaash cut down all the trees and fished all the fish and forced us out of there, that's when our world ended. They made us come all the way up here. This is not our homeland! But we had to

Kiera Brant-Birioukov

kbrantbirioukov@alumni.ubc.ca

1 University of British Columbia, Vancouver, BC V6T 1Z4, Canada 
adapt and luckily we already knew how to hunt and live on the land. We learned to live here".

She became more animated as she went on. Her small hands swayed as she emphasized the words she wanted to highlight. "But then they followed us up here and started taking our children away from us! That's when our world ended again. And that wasn't the last time. We've seen what this... what's the word again?"

Apocalypse

"Yes, apocalypse. We've had that over and over. But we always survived. We're still here".

Waubgeshig Rice (2018, pp. 148-149)

Reading this book in February 2020, my fellow book club members and I had one eye on the book and the other on the news-as we collectively experienced its eerily foreshadowed scenes come to life before our eyes. February turned into March, and the realities of the Covid19 epidemic swept across the world. An air of grief fell across the nation as loved ones fell ill, grocery shelves became bare, and children's playgrounds sat empty with yellow CAUTION tape webbed around the perimeter. The scene described above depicts Aileen, a fictional First Nations Elder and leader in an Anishinaabe community, who speaks of an apocalyptic déjà $v u$. The characters in Rice's (2018) Indigenous science-fiction novel collectively experience the aftermath of a global apocalypse. For Indigenous peoples across Turtle Island (North America) and the world, the end of "life as we know it" has already happened. In the face of such life-altering change, ingenuity and resilience have sustained Indigenous peoples. When it comes to defending ancestral ways of knowing, adaptation and innovation have always been essential. Such a precedent demands to be studied.

As educators prepare for a new education system in light of Covid-19, a turn to Indigenous knowledges and practices of innovation in education is promising. Despite the perceived irrelevance of Indigenous knowledge in our modern, fast-paced world, Indigenous knowledge has proven to be responsive to crises, grief, and renewal. Indigenous cultures, languages, governance, and teachings have survived - not despite colonization but due to complex and responsive knowledge systems that dared to innovate in the face of colonization. There are many lessons to be learned. As a Haudenosaunee scholar in the midst of the unknowns of the Covid-19 pandemic, I offer some lessons as to how In(di)genuity - resilience, innovation, adaptationhas prevailed in times of crisis and what this can offer the Canadian curricular landscape.

Contemporary Indigenous thought, culture, and identity are as fluid, diverse, and relevant as ever. However, settler colonialism across Turtle Island has irreparably limited our ability to self-govern. Other publications have been written detailing the histories of Indigenous education in relation to colonization, Indian residential schools, and the renaissance of autonomous Indigenous education (Battiste and Youngblood Henderson 2018). What I will speak to here is the legacy of resilience, innovation, and adaptation of Indigenous peoples in order to share their In(di)genuity in times of crisis. Lastly, I will show why we need Indigenous knowledge more than ever in a post-Covid-19 curricular agenda.

\section{Positioning indigenous education in Canada}

Education lies at the heart of preparing the next generation of citizens to do well in the world. For the Indigenous peoples of Turtle Island, as with the people of all sovereign nations, education has always been at the core of our self-governance and authority (Brant 
Castellano et al. 2000). The ability, and certainly the right, to self-determination as it concerns our education systems have not always been a given, and yet what sustains us is the drive to reignite these ancient knowledges to benefit future generations. For many Indigenous nations, the fire may no longer be roaring, but the embers have always burned beneath the ashes. Through centuries of forced relocation, the outlawing of our cultural practices, and the seizure of our traditional languages, our traditional ways of knowing have prevailed. They exist today-changed but also renewed. Our knowledges have never been static. Indigenous knowledge systems are forever changing, adapting, adopting, and co-opting new ways of living and being in this world. Some core tenets of Indigenous education, however, have indeed stood the test of time.

Although Canada alone has over 600 distinct First Nations, with 70 diverse languages (Statistics Canada 2019), some collective principles are shared across Indigenous peoples on Turtle Island. One such principle is that Indigenous consciousness is grounded in an innate interconnectedness with land. To be Indigenous is not to simply be from the land but of the land. Battiste and Youngblood Henderson (2000) put this succinctly when they wrote: "Ecologies do not surround Indigenous peoples; we are an integral part of them and we inherently belong to them" (p. 9). Indigenous knowledge systems derive from an intimate and reciprocal relationship with the natural world, acquired through generations of careful observation, trial-and-error, and cumulative knowledge formation (Barnhardt and Kawagley 2005; Cajete 2000; Lipe 2019). In a way, Indigenous thought and knowledge are acquired from the world's oldest longitudinal study. Certainly, however, Indigenous knowledges are more than cultural artifacts of the past. These knowledge systems are living, dynamic, and complex that are responsive to an ever-changing world. Indigeneity, in turn, is living, dynamic, and complex.

Orality, in the form of story and storytelling, is the primary means of Indigenous knowledge transmission. Oral knowledge systems have strict protocols in place to ensure the preservation of authenticity of historical events, stories, and traditional teachings (Archibald 2008). Indigenous oral histories seek to transmit the responsibilities and teachings of balance, sustainability, and reciprocity with all living beings (Longboat et al. 2020). Ancient oral teachings convey the important morals and values that each child needs to be an ethical citizen (Hampton 1995). Oral knowledge also ensures the sustainability of ancestral languages. Ancestral languages derive from the natural world—often said to be reflective of the rhythm of the landscape. As oral knowledge is passed down, our ancestral languages reaffirm "cultural values, shape thought and identity, and describe relationships to people and place" (Hare and Davidson 2015, p. 247). As oral knowledge, it is living, in constant flux with an ever-changing land, community, and sense of self.

Intergenerational teaching is the pedagogical crux of an Indigenous education system. Older siblings, extended family, clan members, and Elders participate in the education of the community's youth. We are all learners; we are all teachers. It is difficult to ascertain a definitive definition of Indigenous education, as each knowledge system is deeply contextual and culturally implicated. For example, for the Haudenosaunee, our Creation Story, the Kayeri Niyorihwa:ke (Four Ceremonies), the Kayaneren'kowa (Great Law of Peace), and the Karihwiyo (Good Message of Handsome Lake) inform who the Haudenosaunee are as Indigenous peoples (Hill 2017). These are our original instructions from the Spirit World. Hence, these teachings inform what we deem to be of the most importance for our children to live in a good way. But this is not the only way to live. There exist many similarities across Indigenous knowledge systems in Canada; however, a nuanced account of Indigenous knowledge must be attentive to the diverse specificities of First Nations, Métis, and Inuit peoples and their respective cultures and histories. What is indeed universal, however, 
is the resilience of Indigenous knowledge in the face of adversity. And yet, while Indigenous knowledge is increasingly a valued discourse of Canadian curricular conversations, it is often understood not in terms of its resilience but only as an eroded consequence of colonization.

\section{Responding to crisis: Resilience, innovation, and adaptation}

Indigenous education, as I use that term here, includes the formal education processes by which Indigenous knowledge is transmitted. Historically, it has referred exclusively to the education of Indigenous youth; however, today it includes the education of and for both Indigenous and settler (non-Indigenous) youth. Indigenous education is now for the benefit of all learners. Just like Indigenous knowledge, Indigenous education is accountable to maintaining a reciprocal relationship with all living beings while holding firm to the ancestral principles that were needed for survival (McGregor 2011; Miller 1996). In striking contrast to Western education systems, there is an evidential lack of institutional structure. Thus, it is best described as Indigenous education, rather than Indigenous schooling. It is important not to misperceive a lack of institutionalized structure as a lack of formal protocols. Indigenous education has clearly defined hierarchical roles and responsibilities and clearly articulated expectations as to what our youth were expected to learn, perform, and accomplish (Miller 1996). Likewise, it was a necessary skill for youth to be proactive, reactive, and receptive to change. Responsive innovation was essential for survival in North America. For generations, Indigenous peoples traveled and resettled across the continent; adopted other nations and their languages, diets, and cultural practices; and pursued new and inventive ways to modernize and adapt while not losing sight of ancestral teachings. An example from my familial Haudenosaunee people in Upstate New York is the adoption of corn, beans, and squash - today referred to as "The Three Sisters". For generations, it has been a staple in our sustenance, yet it was originally gifted from southern Indigenous Mesoamerica.

Since time immemorial, our medicines became refined, alliances and treaties were broken and solidified, and the complexities of educating our youth were in constant flux to respond to the changing needs of our communities. Reconciling the old with the new was a valuable Indigenous asset. Following the arrival of European settlers, however, our cultures and practices were forcefully changed. Contact marked the first crisis-informed renewal of our education systems.

In the early contact era, there was a willingness for Indigenous-settler collaboration, trade, and knowledge sharing. Indigenous language bilingualism was already of political and economic significance prior to the arrival of European settlers however, it became a necessity for both Indigenous and settler peoples to embrace Indigenous and European language bilingualism during the fur trade (Mackey 2004). Also prompted by the fur trade, new beading and fabric options were enthusiastically embraced by Indigenous communities. The modern regalia and beading practices introduced are still widely celebrated. For the Haudenosaunee, trade with early Dutch settlers revolutionized hunting and warfare, as firearms were a welcomed (although not uncontroversial) innovation (Silverman 2016). In return, the newcomers were equally eager to adopt Indigenous inventions in transportation, medicines, democracy, and horticulture (Toulouse 2014). Indigenous communities were keen to embrace innovations brought by settler arrivals, so long as they were not incongruent with ancestral laws and ways of living. Colonization, however, was certainly not defined by its reciprocity. Although there were instances of collaboration, colonization 
ultimately marked the violent genocide of Indigenous peoples, thrusting our ancestors into a state of survivance.

From the early 16th century onward, the colonization of North America inflicted violent, intentional, and aggressive tactics to remove Indigenous peoples from ancestral lands. The historical injustice of colonization was the original "apocalypse" of North America. The haunting legacies of colonization, particularly slavery, white supremacy, and capitalism - termed the "three horsemen of the Apocalypse" by Gerald Horne (2017) - illuminate the African and Indigenous experience of settler colonialism. By the early 17th century, diseases had decimated our ancestral communities. Not only had population numbers declined, but the human cost of losing loved ones had broken spirits. This interrupted the natural processes of intergenerational cultural transmission. As early as the 1660s, reports estimate that some of our Haudenosaunee communities had lost up to $78 \%$ of our population (George-Kanentiio 2020). The heightened impact of diseases and epidemics was due in part to a lack of immunity but also was a consequence of our community-centered lifestyle. Honouring our clan system, we lived with extended families in longhouses, where communal food, dancing, and collective labor were a daily expectation. In response to historic pandemics, we adjusted cultural and familial habits to halt the spread of disease. We still see the legacies of historical pandemics in our social behaviors today. A reluctance to shake hands, avoiding eye contact, and general shyness around strangers are common Haudenosaunee traits today (George-Kanentiio 2020). These behaviors can be traced back to smallpox- and influenza-informed responses to protect our youth and Elders in particular. In the early years of colonization, it was possible to take proactive measures and exercise our right as sovereign nations to educate and protect the youth. However, our capacity to protect and educate was irreparably compromised when children were taken away from their families during the government-created Indian residential schooling system.

The intent of Indian residential schools in Canada was not education but assimilation. The Truth and Reconciliation Commission of Canada (TRC) reported that the separation of Indigenous youth from their families was deemed the most effective means of destroying Indigenous knowledges, cultures, and languages. According to the Final Report (2015) from the TRC, the "cultural genocide" of Indigenous peoples was the consequence of "separat[ing] Aboriginal children from their families and communities to 'civilize' and Christianize them" (p. 4). The legacies of residential schools are experienced in the significant income, health, and education disparities between Indigenous and non-Indigenous Canadians (TRC 2015). Survivors of Indian residential schools experienced irreparable loss of identity, culture, and connection to community. Many Survivors chose not to raise their own children in their language or culture to protect them from the atrocities they endured - creating intergenerational legacies. However, many of our ancestors, youths themselves at the time, whispered the language in secret. Knowledge Keepers held ceremonies underground when it was an incriminating offense. With clear minds and hearts, Indigenous peoples have always known what knowledge is most sacred and worth protecting, against all odds. "We have experienced the colonization of our creation, our ecologies, our minds, and our spirits", Battiste and Youngblood Henderson (2000) wrote. "Yet, even with horrendous losses, we have resisted and endured" (p. 11).

Since the closure of residential schools in the late twentieth century, Indigenous education has demonstrated its relentless commitment to the resurgence of the languages and cultures that residential schools were designed to destroy. In reclaiming ancestral languages, Indigenous language speakers are reclaiming traditional belief systems that cannot be replicated if the languages are lost (Ball and McIvor 2013). Speaking languages at home is the most effective way for youth to learn a language (Norris 1998). Due to the legacy 
of colonization, however, natural language acquisition at home is not viable for the vast majority of communities. Less than $15.6 \%$ of Indigenous peoples in Canada speak their language well enough to converse with others (Statistics Canada 2017).

Coupled with a lack of sustainable funding and dismal attention to this issue by the mainstream curriculum, Indigenous language revitalization initiatives have been forced to seek creative alternatives. A major impediment to language resurgence is the official language policy in place to protect English and French, the only languages mandated in Canadian schools (Vowel 2017). With a lack of support from federal and provincial governments, language education has operated primarily outside of public and mainstream education. Community-based initiatives have offered creative solutions to the seemingly impossible vision of revitalizing languages on the brink of extinction. Language speakers understand the resurgence of ancestral languages not as the "revival" of "dying" languages but as the waking of our languages from a long sleep (Baldwin and Costa 2018). As such, the waking of our languages has been community-centered through language nests (McIvor 2005), digital technologies and apps (Galla 2016), and grassroots immersion schools (White 2009). Whereas Indigenous language education is operating "against time and against the odds" (Ball and McIvor 2013, p. 25), an ethos of resilience has sustained the promise of language resurgence. A genuine and collective commitment to the holistic education of Indigenous youth is revealing what is possible in times of crisis.

\section{Perceived irrelevance of indigenous knowledge}

One of Time's "100 Most Influential Photos of All Time" (Time 2020) is indicative of the Western fascination with the vanishing Indian discourse. Edward S. Curtis' collection of early twentieth-century photography, The Vanishing Race (1904), captures this settler imagination. It depicts (likely staged, as much of Curtis' work was) a group of Navajo men riding their horses away from the camera on a dusty, dirt road. Curtis' image captures the settler fantasy of Indigenous peoples quietly fading into the sunset. Or, as Curtis described it himself, he captured the Native American way of life "passing into the darkness of an unknown future" (Time 2020, para. 1). The vanishing Indian is a popular trope of settler colonialism. The trope perpetuates a settler historical consciousness that, as Tupper (2012, 2020) posits, normalizes the White settler experience of North America so as to position colonization as inevitable, historical, and progressive. Hence, the trope of a vanishing Indian justifies respect and romanticism for the ancient Indian way of life while rendering present Indigenous peoples as "either invisible or as distinctly separate from what is worth knowing" (Tupper 2020, p. 90). By this logic, all "real Indians" have died, and modernity means we have the right to move on... and so should their descendants. Today, we continue to see the trope of the vanishing Indian in sports mascots, controversial butter logos, and costumes at Halloween. These tokenistic caricatures of Indigeneity justify the dehumanization of Indigenous peoples; decontextualized cultural artifacts are free for convenient consumption and disposal. Whereas mascots and "costumes" are slowly making their way out of Canadian classrooms, a nuanced legacy of the vanishing Indian remains embedded in the curricular discourse. This settler historical consciousness continues to permeate our curricular conversations in Canada, in the perceived irrelevance of Indigenous knowledge and education.

Indigenous curricular discourse in Canada has undergone a rapid transformation in the past twenty years. Canadian education has embraced a call for the greater inclusion of Indigenous perspectives, cultures, and histories in the public curriculum for the 
benefit of all students (Hare and Davidson 2015). Prompted by the 1996 Royal Commission on Aboriginal Peoples and the recent work of the 2015 Truth and Reconciliation Commission, Indigenous education has become a mainstream expectation in the curricular conversations of Canadian classrooms. Such calls for action demand greater Indigenous community engagement and required Indigenous education for students across K-12 and post-secondary institutions (Hare 2020). These initiatives have made unprecedented strides in the public knowledge and awareness of First Nations, Métis, and Inuit realities - with a particular focus on the legacy of the Indian residential schooling system.

The responses to such calls for inclusion in the curricular discourse, however, continue to fall short. One such limitation is the continued marginalization of Indigenous knowledge alongside its Euro-Western counterparts. When Indigenous perspectives are included, they are often rendered as supplemental and "add-on", or as an alternative perspective (Battiste 1998; Battiste and Youngblood Henderson 2018). Such cognitive imperialism suggests that Euro-Western knowledge has the greatest legitimacy (Battiste 2013). The danger of rendering Indigenous knowledge as supplemental - particularly if it is "optional" and left to the teacher's discretion-implies that Indigenous ways of knowing are less relevant and necessary in today's fast-paced world. Such curricular discourse suggests that Indigenous knowledge may be of cultural and artistic interest, but it is not valued where "real knowledge" is concerned, particularly in the core academic subjects, such as the sciences, mathematics, resource management, and economics. Indigenous knowledge is not of most worth in Canadian curricular discourse. If curriculum centers on Western knowledge as foundational and Indigenous knowledge as purely anecdotal, the curricular agenda will not be interrupted so as to convey the legitimacy of Indigenous knowledges in contemporary Canada. The legitimacy of nonWestern knowledge is essential in the construction of a socially just curriculum -in the decolonization of Western imperialism, or what Paraskeva (2016) has termed the curriculum epistemicide. The epistemological universality of Western thought acknowledges that Indigenous thought was of historical significance but would not (could not?) modernize with the times-instead, victim-blaming the vanishing Indian who failed to assimilate. The foremost threat to Indigeneity is not modernity but epistemological hegemony. Despite the misconception that Indigenous knowledge is primitive and outdated, responsive innovation and adaptation have always been the primary principles by which Indigenous knowledge remains extant.

A turn to the anthropological roots of Indigenous knowledge in the academy helps us to unpack the oxymoron of Indigenous knowledge as modern. The anthropological concept of diffusionism suggests that Indigenous thought lacks the wherewithal to innovate and adapt. Battiste and Youngblood Henderson (2000) argue that diffusionism perpetuates the idea that the ability to assimilate to Eurocentric values and knowledge systems is "progress". Indigenous knowledge, however, has remained vehemently resistant to assimilation, despite the permeance of colonization. Conversely, innovation and adaptation have always been embedded in Indigenous knowledge systems. Our knowledges, languages, cultures, and practices have always responded to crisis, conflict, and change without succumbing to an assimilative defeat. Returning to Curtis' (1904) photo, "The Vanishing Race", diffusionism reaffirms the image of the Native American archetype riding off into the sunset of its own demise. And yet, Indigenous peoples are still here, no less authentically Indigenous, just authentically modern. In the face of an unprecedented pandemic and its unprecedented impact on present-day educational crises, I offer some considerations as to how a re/turn to Indigenous knowledge might offer lessons and direction. 


\section{Lessons to bring forward}

A conversation about Covid-19 and Indigenous communities cannot begin without attending to the healthcare crisis for Indigenous peoples around the world. Indigenous communities are disproportionately at risk of suffering the worst consequences of Covid-19 (CEJIL 2020; UN EMRIP 2020). Basic social determinants of health fail to be met within Indigenous communities, primarily due to access to quality health care, safe drinking water, and lack of food security. According to the United Nations' Expert Mechanism on the Rights of Indigenous Peoples (UN EMRIP 2020): "Covid-19 has and will continue to exacerbate an already critical situation for many indigenous peoples: a situation where inequalities and discrimination already abound" (p. 1). The two most basic principles of Covid-19 transmission reduction--physical distancing and handwashing — struggle to be feasible in our Indigenous communities, where people are forced to cohabitate and where boil-water advisories are routine. However, Indigenous health care professionals have been clear in their message to Indigenous communities: We have faced crises before, and we shall make it through by relying on our inherited ancestral teachings (First Nations Health Authority 2020).

A profound sense of perseverance and commitment to future generations is reaffirmed in our cultural expressions as Indigenous peoples. Hence, our response to past and presentday crises is intertwined with responsibilities to future generations. Living oral histories make pandemics of the past feel not so distant to us in our Covid-19 realities of 2021. Whereas shelter-in-place and self-isolation practices are certainly as foreign to Indigenous peoples as they are for all global communities, the ethical and civic responsibilities embedded in Covid-19 measures are congruent with the Indigenous perspective that the individual is responsible for the collective. As Māori scholar and educator Linda Tuhiwai Smith (2020) expressed it, response measures to Covid-19 complement our ancestral obligations to the relational, reciprocal, and collective sense of putting the community before the self. Stay-at-home, masks, physical distancing, and vaccination demand a public acceptance of civic duty to protect others through the sacrifice of self-interest. The acceptance of sacrifice-for-the-collective is particularly evident in less vulnerable populations who might otherwise be healthy even if they contract the virus but risk spreading it to others. Supporting Elders and putting the "whole before the individual" have been central practices in Indigenous communities for generations (Smith 2020). Smith argues that the skills of "survivance and resilience" are embedded in traditional Indigenous healing and cultural practices. We have survived and thrived in the wake of an apocalypse before. We shall make it through as we have always done.

At a time that otherwise would have been Spring break for Canadian students, the spread of coronavirus shut down schools one province and territory at a time. Between March and April 2020, Canadian provinces and territories took independent steps to shut down schools, seemingly temporarily. As the permanence of the novel virus set in, decisions to keep schools permanently closed quickly became a reality. In Ontario, the initial decision on March 12, 2020 was to shut down schools for only three weeks to allow time to slow the spread of the virus and protect student safety. Less than two weeks later, however, Ontario Premier Doug Ford announced schools would not reopen as early as initially anticipated (Westoll 2020). By mid-May, Ontario schools made the decision to revoke the possibility of students returning to in-person classrooms for the remainder of the school year, which ends in June (Rushowy 2020). Youth and their families across the country grappled with the implications of the virus for education-in particular, with students "falling behind" in their schooling (Collie 2020). A recent study from the Angus Reid Institute, which 
assessed the impact of Covid-19 on Canadian youth ages 10-17, noted that only $15 \%$ of youth expressed concern about contracting the virus, while $22 \%$ said their parents getting sick from coronavirus was a "big worry" for them. Interestingly, however, top concerns for youth were that they were missing out on the current and next school year (27\% and 29\%, respectively) (Angus Reid Institute 2020). Because the modern Canadian education system has so thoroughly conflated "education" with formal schooling, it is little wonder that our youth carry these anxieties of a compromised education while schools are closed. I invite Canadian educators and parents to put down the fears and anxieties we are harnessing over our youth "falling behind" in their education. There is enough to be worried about.

First, let us grieve what has been lost. In Haudenosaunee societies, our condolence ceremonies give us the teaching of carrying the burden of grief, meaning that when one clan (family) has lost a family member, the other clans have responsibilities to help carry the mourning process. In this view, grief and healing are a communal responsibility. Whether we have been immediately impacted by the loss of a loved one due to the tragedy of Covid19 , or not, we can still feel the residual and collective mourning. Do not rush this. Let us grieve for the loss of time, opportunity, relationships, and love. Productivity and progress should not be our priority unless such busyness assists in our bereavement. Our priorities should be on the most vulnerable, such as those whose grief is too heavy to carry alone, or who are most at risk. Historically and presently in Indigenous communities, our most vulnerable (and hence most protected) peoples are our Elders and youth. Our Elders are the knowledge keepers who keep our histories and teachings alive. The youth are the most connected to the sacredness of ecology and Spirit World. How are we protecting those lives most precious to our collective humanity? How are we nourishing their well-being? How are school closures lifting or hindering their spirits? Presented with school closures, too many Indigenous youth are less concerned with "falling behind" in their studies than they are with receiving the basic necessities that many schools provide, such as breakfast and lunch. Youth will continue to learn, inquire, brainstorm, and problem-solve outside of structured educational programming, but their ability to do so is compromised if they do not have food to eat or clean water to drink. If holistic education is truly a curricular and pedagogical priority, now is the time to ensure that our youth and their families are supported.

In this time of pause, as we collectively do our part to stop the spread of coronavirus, there is also an opportunity to benefit from the intergenerational learning that public K-12 schooling fails to account for. While the formalized structure of mainstream schooling streams students by age, a shelter-in-place education at home presents an organic opportunity for siblings, parents, grandparents and other intergenerational caretakers to reconnect and reimagine our intergenerational roles. Indigenous scholar Dwayne Donald (2019) argues that we need to reimagine curriculum so as to problematize the homo economicus and the forgetting of our human dependence on sacred ecology to live. Eurocentric curriculum is a contested space, he posits, where we need to disrupt the education system that promotes the anthropocentric individual "who is primarily motivated by economic self-interest and the material gains that come with it" (Donald 2019, p. 105). With schools eager to resume classes so as to "re-open the economy", one must stop to question the ethicality of compromising student, teacher, and community well-being for the sake of the economy. With economic pressures looming, the province of Quebec was confident in its ability to resume face-to-face instruction while keeping students and staff safe-only two weeks in and with over 40 staff and students testing positive for Covid-19 (Lowrie 2020). First Nations schools in Quebec, however, exercised their self-determination as sovereign nations and decided to keep schools closed: "Our traditional teachings place so much value 
on our individual responsibility to care for the welfare of the collective. This philosophy has never been more relevant" (Deer 2020). What is the human cost of the economy? Where is the innovation to respond to the present-day crisis - or do we merely wish to resume "business as usual"?

A renewal and reconnection with place and land is also made possible in this slowness. For Indigenous peoples, a return to the land has been foretold in our ancient prophecies. In light of the Covid-19 pandemic-related school closures, some Indigenous communities have embraced the educational possibilities of leaving the K-12 classroom and rebuilding a reciprocal relationship with the land. In Canada's North, a high school in Iqaluit, Nunavut, has embraced the possibility of a "practical" land-based educational program. When classes were canceled on April 17, students at the Inuksuk High School were encouraged to stay home, spend time on the land, and submit evidence of land-based learning experiences to be recognized for their high school credits (Patar 2020). The program recognizes land-based learning as a fundamental skill for Indigenous youth, most of whom are Inuit. Beadwork, snowmobile maintenance, fishing, and hunting are all examples of recent projects students submitted toward their 25-hours for one credit (Patar 2020).

We see evidence of other First Nations, Inuit, and Métis communities that see school closures not as a catastrophe but as an "opportunity ... to reintroduce their youth back onto the land" (Last 2020). At the Kativik Regional School Board in northern Quebec, the director of educational services called upon parents to teach their children "how to hunt, fish, and be safe on the land" (Last 2020). For grades 11 and 12 students in Quebec, who require the completion of standardized credits to graduate, the Cree School Board offered printable and land-friendly activities, so that youth who wish to participate in the annual goose hunt can continue their learning "in the bush" (Bell 9 April 2020). Two months into a new land-based program, Garrick Schmidt, a grade- 8 teacher in the Ochapowace First Nation in southern Saskatchewan, had to adapt his teachings to comply with pandemic physical distancing measures. Schmidt began to record his land-based lessons and posted them online. Not only were his students benefiting from his virtual land-based teachings, but soon youth and adults across Canada were accessing his videos. On thinking about the importance of sharing these teachings, Schmidt said it is "vital that children, students, and young adults [are] learning these ways", as "a lot of things were forgotten", due to "residential schools and the day school programs" that forcefully sought to interrupt this traditional knowledge transmission (Giesbrecht 2020). An eagerness to be creative and innovate not only sustains an education system in a time of crisis but provides an opportunity to reimagine what is done, why it is done, and what we wish to bring forward into our new normal.

What lessons do we take forward into a post-Covid-19 curriculum? In a time of renewal and change, what legacies will we leave for future generations to inherit? For Indigenous communities, our ancestors left legacies of their resilience and innovation in times of crisis. Future generations of Indigenous youth will look at this time and see evidence of our traditional teachings embedded in our response: an honoring of the slowness, grief, and renewal; cherishing the well-being of our youth and Elders; a return to the land; and, above all, a communal responsibility to the collective well-being. I invite Canadian educators to attend to the settler historical consciousness embedded in our current curricular landscape. Consider the implications of Indigenous resilience, innovation, and adaptation and how this informs or renews the curricular discourse. The prevalence of the vanishing Indian discourse dominates many curricular constructs and subject areas, insofar as Indigenous education is often rendered marginal, merely of historical or anecdotal value. As we navigate the unprecedented consequence of Covid-19 in our lives and in our education systems, the time to acknowledge the contemporary 
value of Indigenous knowledge is overdue. In what ways does Indigenous education reaffirm our commitment to the well-being of youth, Elders, and the broader community? The pursuit of In(di)genuity in our curricular response to Covid-19 might be our legacy to future generations.

\section{References}

Angus Reid Institute (2020). Kids \& Covid-19: Canadian children are done with school from home, fear falling behind, and miss their friends. Vancouver, British Columbia: Angus Reid Institute. http://angus reid.org/covid19-kids-opening-schools/.

Archibald, J. (2008). Indigenous storywork: Educating the heart, mind, body, and spirit. Vancouver, British Columbia: University of British Columbia Press.

Baldwin, D., \& Costa, D. J. (2018). Myaamiaataweenki: Revitalization of a sleeping language. In K. L. Rehg \& L. Campbell (Eds.), The Oxford handbook of endangered languages (pp. 553-570). Oxford: Oxford Unviersity Press.

Ball, J., \& McIvor, O. (2013). Canada's big chill: Indigenous languages in education. In C. Benson \& K. Kosonen (Eds.), Language issues in comparative education: Inclusive teaching and learning in nondominant languages and cultures (pp. 17-38). Boston, MA: Brill Sense Publishers.

Barnhardt, R., \& Kawagley, A. (2005). Indigenous knowledge systems and Alaska native ways of knowing. Anthropology \& Education Quarterly, 36(1), 8-23.

Battiste, M. (1998). Enabling the autumn seed: Toward a decolonized approach to aboriginal knowledge, language and education. Canadian Journal of Native Education, 22(1), 16-27.

Battiste, M. (2013). Decolonizing education: Nourishing the learning spirit. Vancouver, British Columbia: University of Columbia Press.

Battiste, M., \& Youngblood Henderson, J. S. (2018). Compulsory schooling and cognitive imperialism: A case for cognitive justice and reconciliation with Indigenous peoples. In K. Trimmer, R. Dixon, Y. Stewart Findlay (Eds.), The Palgrave handbook of education law for schools (pp. 567-583). London: Palgrave Macmillan.

Battiste, M., \& Youngblood, J. (2000). Protecting Indigenous knowledge and heritage: A global challenge. Vancouver, British Columbia: University of British Columbia.

Bell, S. (2020, April 9). Cree learning in northern Quebec moves online. CBC News. https://www.cbc.ca/ news/canada/north/covid-19-cree-school-board-online-learning-platform-1.5527442.

Brant Castellano, M., Davis, L., \& Lahache, L. (Eds.) (2000). Aboriginal education: Fulfilling the promise. Vancouver, British Columbia: University of British Columbia.

Cajete, G. (2000). Indigenous knowledge: The Pueblo metaphor of Indigenous education. In M. Battiste (Ed.), Reclaiming Indigenous voice and vision (pp. 181-191). Vancouver, British Columbia: University of British Columbia Press.

CEJIL [Centro por la Justicia y el Derecho Internacional] (2020, April 21). Covid-19: The survival of indigenous peoples is at risk. Buenos Aires: CEJIL. https://cejil.org/en/covid-19-survival-indigenous-peopl es-risk.

Collie, M. (2020, May 21). With schools closed by coronavirus, is my child falling behind? Global News. https://globalnews.ca/news/6962955/coronavirus-falling-behind-school/.

Deer, J. (2020, May 1). Most First Nations elementary schools to stay closed as Quebec moves to reopen. CBC News. https://www.cbc.ca/news/indigenous/first-nations-schools-quebec-stay-closed-1.5550927.

Donald, D. (2019). Homo economicus and forgetful curriculum. In H. Tomlins-Jahnke, S. Styres, S. Lilley, \& D. Zinga (Eds.), Indigenous education: New directions in theory and practice (pp. 103-125). Edmonton, Alberta: University of Alberta Press.

First Nations Health Authority (2020, April 1). Senior medical officer Dr. Nel Wieman of the FNHA talks about Covid-19. https://www.youtube.com/watch?v=4yd8ZNmF7ek.

Galla, C. K. (2016). Indigenous language revitalization, promotion, and education: Function of digital technology. Computer Assisted Language Learning, 29(7), 1137-1151.

George-Kanentiio, D. (2020, March 19). How the Mohawks responded to historical plagues. Indianz. https:// www.indianz.com/News/2020/03/19/doug-georgekanentiio-how-the-mohawks-res.asp.

Giesbrecht, L. (2020, April 27). Sask. Teacher keeping land-based learning alive online during pandemic. Regina Leader-Post. https://leaderpost.com/news/saskatchewan/sask-teacher-keeping-land-based-learn ing-alive-online-during-pandemic. 
Hampton, E. (1995). Towards a redefinition of Indian education. In M. Battiste \& J. Barman (Eds.), First Nations education in Canada: The circle unfolds (pp. 5-46). Vancouver, British Columbia: University of British Columbia Press.

Hare, J. (2020). Reconciliation in teacher education: Hope or hype? In A. Phelan, W. F. Pinar, N. Ng-AFook, \& R. Kane (Eds.), Reconceptualizing teacher education worldwide: A Canadian contribution to a global challenge (pp. 19-38). Ottawa, Ontario: University of Ottawa Press.

Hare, J., \& Davidson, S. F. (2015). Learning from Indigenous knowledge in education. In D. Long \& O. P. Dickason (Eds.), Visions of the heart: Canadian Aboriginal issues (4th ed., pp. 241-262). Oxford: Oxford University Press.

Horne, G. (2017). The apocalypse of settler colonialism: The roots of slavery, white supremacy, and capitalism in 17th century North America and the Caribbean. New York, NY: Monthly Review Press.

Hill, S. M. (2017). The clay we are made of: Haudenosaunee land tenure on the Grand River. Winnipeg, Manitoba: University of Manitoba Press.

Last, L. (2020, May 19). Why on-the-land educators see opportunity in a global pandemic. CBC News. https://www.cbc.ca/news/canada/north/on-the-land-education-covid-19-1.5571602.

Lipe, D. (2019). Indigenous knowledge systems as the missing link in scientific worldviews. In H. Tomlins-Jahnke, S. Styres, S. Lilley, \& D. Zinga (Eds.), Indigenous education: New directions in theory and practice (pp. 453-481). Edmonton, Alberta: University of Alberta Press.

Longboat, D. R., Andrejs, K., \& Young, K. (2020). Developing curriculum through engaging oral stories: A pedagogy for reconciliation and eco-justice-oriented education. In K. R. Llewellyn \& N. Ng-A-Fook (Eds.), Oral history, education and justice: Possibilities and limitations for redress and reconciliation (pp. 183-196). London: Taylor \& Francis.

Lowrie, M. (2020, May 29). Amid reopening, Quebec says 41 students and staff have tested positive for Covid-19. Global News. https://globalnews.ca/news/7003307/quebec-schools-coronavirus-cases/.

Mackey, W. F. (2004). Chapter 23: Bilingualism in North America. In T. K. Bhatia \& W. C. Ritchie (Eds.), The handbook of bilingualism (pp. 607-641). Oxford: Blackwell Publishing.

McGregor, H. E. (2011). Inuit education and schools in the Eastern Arctic. Vancouver, British Columbia: UBC Press.

McIvor, O. (2005). Building the nests: Indigenous language revitalization in Canada through early childhood immersion programs. [PhD dissertation]. University of Victoria.

Miller, J. R. (1996). Shingwauk's vision: A history of Native residential schools. Toronto, Ontario: University of Toronto Press.

Norris, M. J. (1998). Canada's Aboriginal languages. Canadian Social Trends (Winter), 8-16.

Paraskeva, J. M. (2016). Curriculum epistemicide: Towards an itinerant curriculum theory. Routledge.

Patar, D. (2020, May 7). Iqaluit high school launches practical learning program. Nunatsiaq News. https:// nunatsiaq.com/stories/article/inuksuk-high-school-launches-practical-learning-logbook-program/.

Rice, W. (2018). Moon of the crusted snow. Toronto, Ontario: ECW Press.

Rushowy, K. (2020, May 19). Ontario schools will remain closed until the end of June. The Star. https:// www.thestar.com/politics/provincial/2020/05/18/ontario-classes-are-cancelled-for-rest-of-theschool-year.html.

Silverman, D. (2016). Thundersticks: Firearms and the violent transformation of Native America. Cambridge, MA: Harvard University Press.

Smith, L. T. (2020, April 7). Not our apocalypse [“Accessing Deep Indigenous Knowing” daily webinar by Indigenous Knowledge Network]. https://indigenousknowledgenetwork.net/webinar-2020/.

Statistics Canada (2017). The Aboriginal languages of First Nations people, Métis and Inuit: Census of population, 2016. https://www12.statcan.gc.ca/census-recensement/2016/as-sa/98-200-x/2016022/ 98-200-x2016022-eng.pdf.

Statistics Canada (2019). Aboriginal peoples in Canada: Key results from the 2016 Census. Ottawa, Ontario: Statistics Canada. https://www150.statcan.gc.ca/n1/daily-quotidien/171025/dq171025aeng.htm.

Time (2020). The vanishing race: Edward S. Curtis, 1904. 100 photos: The most influential images of all time. http://100photos.time.com/photos/edward-curtis-vanishing-race.

Toulouse, P. R. (2014). A truthful narrative: Bringing First Nations, Métis and Inuit contributions to the world into the K-12 curriculum. Education Canada Network (pp. 20-24). Toronto, Ontario: Canadian Education Association.

Truth and Reconciliation Commission of Canada (2015). Honouring the truth, reconciling for the future: Summary of the final report of the Truth and Reconciliation Commission of Canada. http:// www.trc.ca/websites/trcinstitution/File/2015/Honouring_the_Truth_Reconciling_for_the_Future_ July_23_2015.pdf. 
Tupper, J. (2020). Cracks in the foundation: (Re)storying historical consciousness. In K. Lewellyn \& N. Ng-A-Fook (Eds.), Oral history, education and justice: Possibilities and limitations for redress and reconciliation (1st ed., pp. 88-104). Ottawa, Ontario: University of Ottawa Press.

Tupper, J. A. (2012). Treaty education for ethically engaged citizenship: Settler identities, historical consciousness and the need for reconciliation. Citizenship Teaching \& Learning, 7(2), 143-156.

UN EMRIP [United Nations Expert Mechanism on the Rights of Indigenous Peoples] (2020, April 6). Covid-19 yet another challenge for indigenous peoples. Geneva: Office of the United Nations High Commissioner for Human Rights (OHCHR). https://www.un.org/development/desa/indigenouspeopl es/wp-content/uploads/sites/19/2020/04/EMPRIP-English.pdf.

Vowel, C. (2017, November 16). Why Indigenous languages should be taught alongside French and English. Macleans. https://www.macleans.ca/society/why-indigenous-languages-should-be-taught-alongsidefrench-and-english/.

Westoll, N. (2020, March 23). Coronavirus: Ontario schools won't reopen on April 6, Premier Doug Ford says. Global News. https://globalnews.ca/news/6719180/coronavirus-ontario-schools-doug-ford/.

White, L. (2009). Free to be Kanien'kehaka: A case study of educational self-determination at the Akwesasne Freedom School. Unpublished doctoral dissertation. Tucson, AZ: University of Arizona. https:// ais.arizona.edu/dissertation/free-be-kanienkehaka-case-study-educational-self-determination-akwes asne-freedom-school.

Publisher's Note Springer Nature remains neutral with regard to jurisdictional claims in published maps and institutional affiliations.

Kiera Brant-Birioukov is a PhD candidate in the Department of Curriculum \& Pedagogy at the University of British Columbia. Kiera is a proud member of the Mohawks of the Bay of Quinte, and she lives in her ancestral community of Tyendinaga Mohawk Territory. She was raised by strong parents and grandparents who taught her the importance of language, community, and identity, which she carries with her in her work as an educator and researcher. Her dissertation is grounded in curriculum theory, where she is theorizing the possibilities of estrangement/homecoming in education from a Haudenosaunee worldview. She has published on theorizing reconciliatory pedagogies, reconceptualizing Indigenous teacher education, and using autoethnographic métissage to deconstruct systems of colonialism in higher education. 